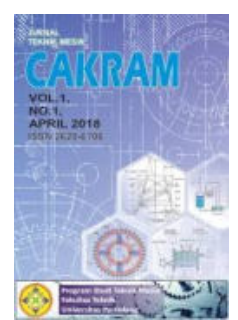

\title{
ANALISIS FATIGUE LIFE STRUKTUR DUDUKAN BOGIE MONORAIL UTM 125 KAPASITAS 24 TON MENGGUNAKAN METODE FINITE ELEMENT
}

\author{
Muhammad Awwaluddin ${ }^{1}$ \\ ${ }^{1}$ Program Studi Teknik Mesin, Universitas Pamulang, Jl. Surya Kencana No.1, Tangerang \\ Selatan, Indonesia \\ E-mail : dosen00543@unpam.ac.id.
}

Masuk: 16 Agustus 2019

Direvisi : 5 September 2019

Disetujui : 22 September 2019

\begin{abstract}
Abstrak: Struktur dudukan bogie pada monorail UTM 125 dengan kapasitas 24 ton perlu dilakukan analisis fatigue. Analisis fatigue merupakan salah satu metode untuk memperkirakan resiko kegagalan, kerusakan dan usia dari suatu struktur yang diakibatkan oleh beban berulang. Dengan analisis fatigue, resiko kegagalan struktur dapat diperkecil sehingga dapat meminimalkan kerugian yang lebih besar. Analisis fatigue dilakukan menggunakan software finite element mengikuti diagram proses analisis. Pembebanan yang diberikan adalah beban aktual desain, beban akibat angin dan beban pada saat kereta berbelok. Dari analisis fatigue pada struktur bogie tersebut didapatkan hasil yang sudah masuk dalam katagori aman atau high cycle (infinite cycle).
\end{abstract}

Kata kunci : analisis struktur, fatigue Struktur, kerusakan struktur, Monorail.

Abstract: Bogie support on monorail UTM 125 structure with 24 ton capacities need to be fatigue analysis. Fatigue analysis is one of methods to estimate the risk of failure, damage, and age of structure caused repeated load. By fatigue analysis, the risk of structure failure and greater losses can be minimized. Fatigue analysis was performed by finite element software following the analysis process diagram. Loading given is actual load, wind load, and load when the train turns. From the fatigue analysis on the bogie structure can be said safe because entry in high cycle (infinite cycle).

Key word: Fatigue Structure, failure Structure, Monorail Structure

\section{PENDAHULUAN}

Proses perancangan struktur dudukan bogie merupakan proses yang rumit yang harus mempertimbangkan banyak faktor termasuk diantaranya analisis fatigue. analisis diperlukan agar dapat memastikan struktur dalam memenuhi fungsinya dan mampu bertahan berdasarkan umur layanan yang telah ditetapkan. Dalam perencanaan desain dudukan boogie akan dikenakan beban dinamis lebih besar dibandingkan struktur yang lain dikarenakan pada struktur tersebut merupakna tumpuan dari semua beban yang ada pada gerbong kereta. Kriteria desain yang 


\section{Jurnal Teknik Mesin: CAKRAM 2019}

Muhammad Awwaluddin, Analisis Fatigue Life Struktur Dudukan Bogie Monorail Utm 125 Kapasitas 24 Ton Menggunakan Metode Finite Element

ditetapkan untuk tiap struktur pada perancangan monorail berbeda beda, bergantung pada kondisi pembebanan. Pada dudukan bogie kegagalan sering terjadi diakibatkan adanya pembebanan berulang sehingga menyebabkan kelelahan struktur dan perlu untuk diwaspadai dan dilakukan analisis.

Kegagalan struktur dapat terjadi pada struktur yang paling sederhana sampai dengan struktur yang sangat komplek, sehingga dapat berakibat pada kerugian dan bahkan dapat mengakibatkan korban Jiwa [1-4].

Analisa kelelahan merupakan metode yang biasa dipakai untuk mengetahui penyebab kegagalan pada struktur. Tujuan analisa adalah untuk mengetahui penyebab kegagalan pada struktur, sehingga resiko adanya kerusakan dan kerugian yang besar dapat dihindari. Dalam analisis kelelahan biasanya mengikuti kurva S-N [5].

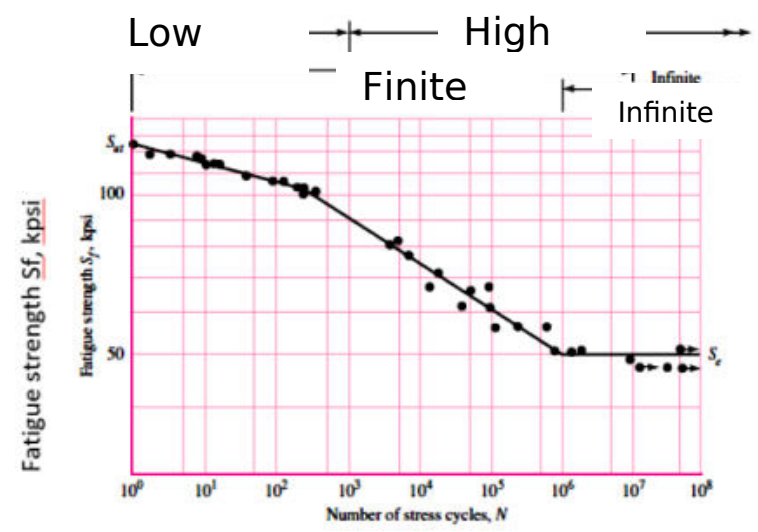

Number of stress

Gambar 1. Diagram kurva S-N yang di plot dari hasil uji kelelahan pada beban aksial.

Dari gambar diatas didapat bahwa untuk $\mathrm{N}$ cycle $10^{\circ}-10^{3}$ dikategorikan siklus rendah (low cycle), $10^{3}-10^{6}$ dikategorikan siklus tinggi (high cycle) tetapi masih dalam finite cycle, sedangkan diatas $10^{6}$ dikategorikan kekal (infinite cycle).

\section{METODOLOGI}

Proses analisis fatigue life pada struktur bogie monorail UTM-125 mengikuti diagram alir pada gambar 2 dibawah. Pada Gambar 2 dibawah dijelaskan bahwa nilai $\mathrm{R}$ yang diberikan adalah 0,67, tipe rasio pembebanan 0,67. Waktu yang diberikan adalah 1s. Teori koreksi menggunakan gerber, tipe analisis yang dipilih adalah stress life, dan komponen tegangan yang diberikan adalah equivalent von-mises. Untuk siklus yang diberikan adalah 1, berarti bahwa tiap 1 siklus berlangsung selama 1 detik, sehingga frekuensinya adalah $1 \mathrm{~Hz}$. 


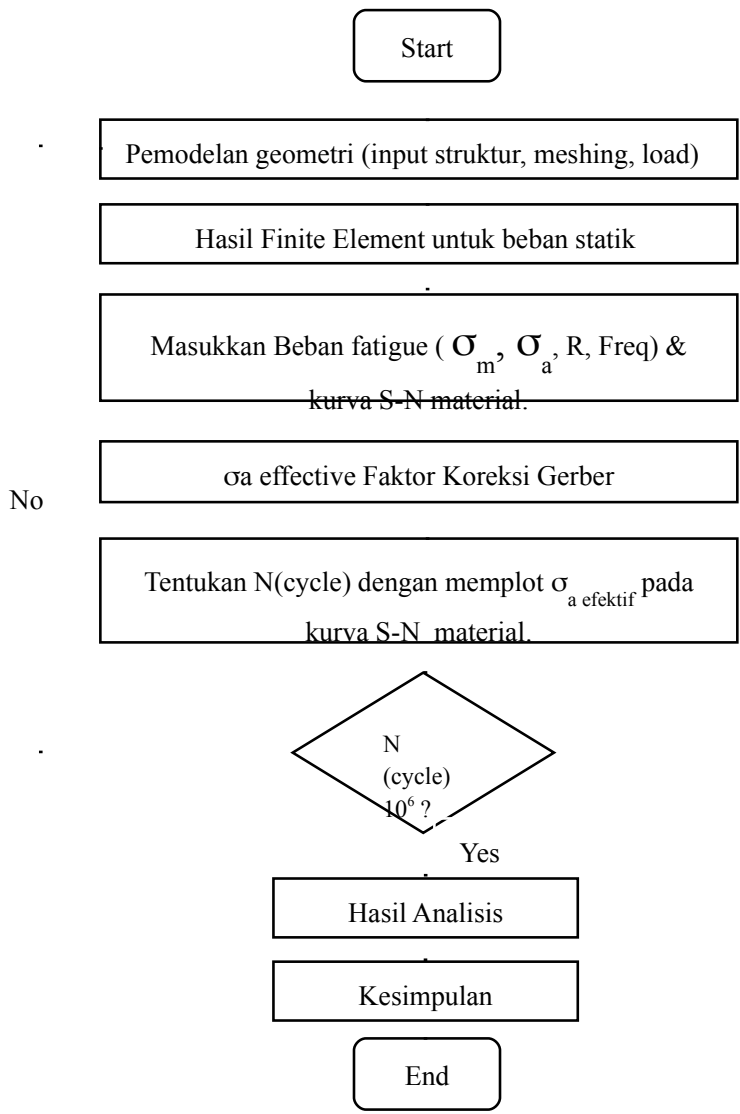

Gambar 2. Diagram Proses Analisis

Fatigue

Pada diagram proses analisis, pemodelan menjadi kunci utama dalam memulai proses analisis. Jika model yang diinputkan dalm software tidak clear maka akan memberikan hasil yang kurang bagus. Langkah penentuan batasan kondisi ( support) dan pembebanan yang diberikan juga harus disesuaikan dengan kondisi actual di lapangan. Tahapan selanjutnya adalah berikan asumsi berupa $\sigma_{\max }, \sigma_{\mathrm{m}}, \mathrm{R}, \mathrm{F}$, serta mean stress dan faktor koreksi Gerber mean stress. asumsi R adalah 0,67 dan Frekuensi $1 \mathrm{~Hz}$, untuk sekali siklus. 


\section{Jurnal Teknik Mesin: CAKRAM 2019 \\ Muhammad Awwaluddin, Analisis Fatigue Life Struktur Dudukan Bogie Monorail Utm 125 Kapasitas 24 Ton Menggunakan Metode Finite Element}

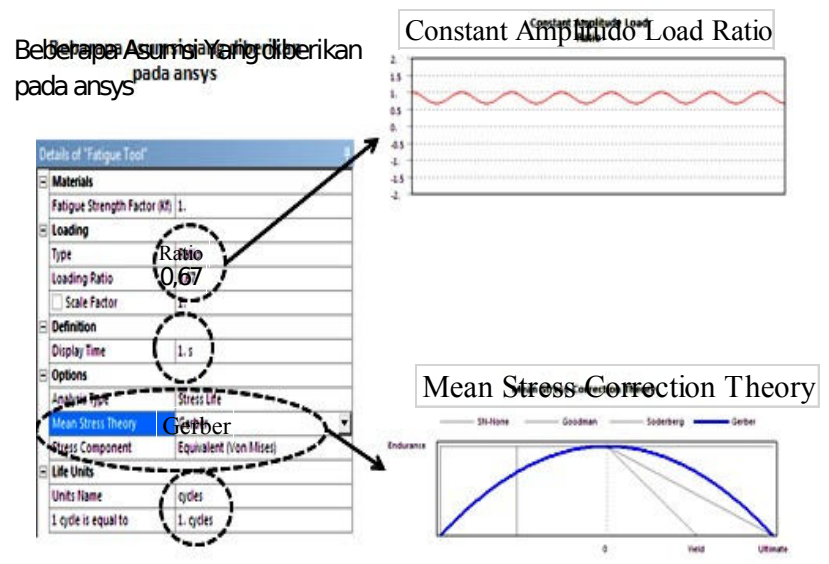

Gambar 3. Asumsi yang diberikan pada software

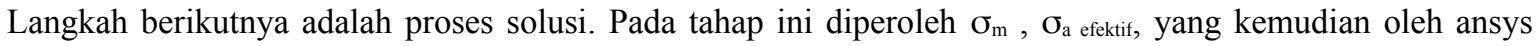
akan di plot ke dalam kurva S-N dengan inputan tipe interpolasi sehinga diperoleh data berupa fatigue life. Hasil komparasi perhitungan secara manual dengan software ansys dapat dilihat pada Gambar 4.

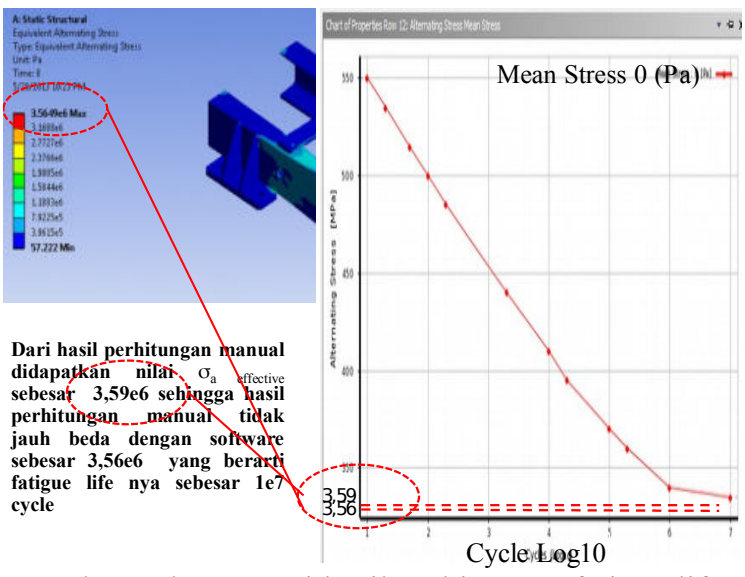

Gambar 4. komparasi hasil perhitungan fatigue life.

Gambar 4. merupakan hasil perhitungan manual bernilai 3,59e6 Pa. Hasil perhitungan pada software ansys yang bernilai 3,56e6 Pa. Hasil perhitungan fatigue life ansys sebesar 1e7 cycle. Langkah selanjutnya adalah proses validasi, dilanjutkan tahap analisis hasil dan kesimpulan.

\section{PEMODELAN FINITE ELEMENT}

Pemodelan finite element diperlukan untuk mendapatkan nilai tegangan. Pada struktur dudukan bogie monorail UTM-125 digunakan software solid work yang kemudian di importkan ke dalam software finite element analysis, FEA) ANSYS 14.0 tahun 2012. Desain awal dibuat oleh PT. MBW [6] dan perubahan desain dilakukan dalam penelitian ini. Material yang dipakai adalah SS $400[9,10]$. Data struktur mengikuti tabel 1. dan gambar struktur seperti pada Gambar 5.

Tabel 1. Profil dan Dimensi Struktur Dudukan bogie

\begin{tabular}{|c|c|c|}
\hline No & Keterangan & Dimensi \\
\hline 1 & mp tgh cross channel: 1 & UNV $150 \mathrm{~mm}, \mathrm{l}=$ \\
\hline
\end{tabular}


Jurnal Teknik Mesin: CAKRAM 2019

Muhammad Awwaluddin, Analisis Fatigue Life Struktur Dudukan Bogie Monorail Utm 125 Kapasitas 24 Ton Menggunakan Metode Finite Element

\begin{tabular}{|c|l|l|}
\hline & dan 2 & $1900 \mathrm{~mm}$ \\
\hline 2 & $\begin{array}{l}\mathrm{mp} \text { tgh spring pad: } 1,2,3, \\
4\end{array}$ & $\begin{array}{l}\mathrm{t}=20 \mathrm{~mm}, 1=100 \\
\mathrm{~mm}, \mathrm{p}=260 \mathrm{~mm}\end{array}$ \\
\hline 3 & $\begin{array}{l}\mathrm{mp} \text { tgh spring pad } \\
\text { stiffener: } 1,2,3,4,5,6,7, \\
8 .\end{array}$ & $\begin{array}{l}\text { Segitiga, } \mathrm{t}=150 \\
\mathrm{~mm}, \mathrm{a}=80 \mathrm{~mm},\end{array}$ \\
\hline 4 & $\mathrm{mp}$ tgh bolster pad: 1 & Square $380 \mathrm{~mm}$ \\
\hline 5 & $\begin{array}{l}\mathrm{mp} \text { tgh cross flat bar: } 1,2, \\
3,4\end{array}$ & $\begin{array}{l}\mathrm{p}=685 \mathrm{~mm}, \mathrm{l}=52 \\
\mathrm{~mm}\end{array}$ \\
\hline 6 & $\begin{array}{l}\mathrm{mp} \text { tgh cross channel } \\
\text { beam : } 1,2\end{array}$ & Siku $60, \mathrm{p}=250 \mathrm{~mm}$ \\
\hline 6 & $\begin{array}{l}\mathrm{mp} \text { tgh cross channel } \\
\text { beam revision: } 1,2\end{array}$ & $\begin{array}{l}\text { Pelat } \mathrm{p}=230 \mathrm{~mm}, \mathrm{l}= \\
60 \mathrm{~mm}, \mathrm{t}=15 \mathrm{~mm}\end{array}$ \\
\hline
\end{tabular}

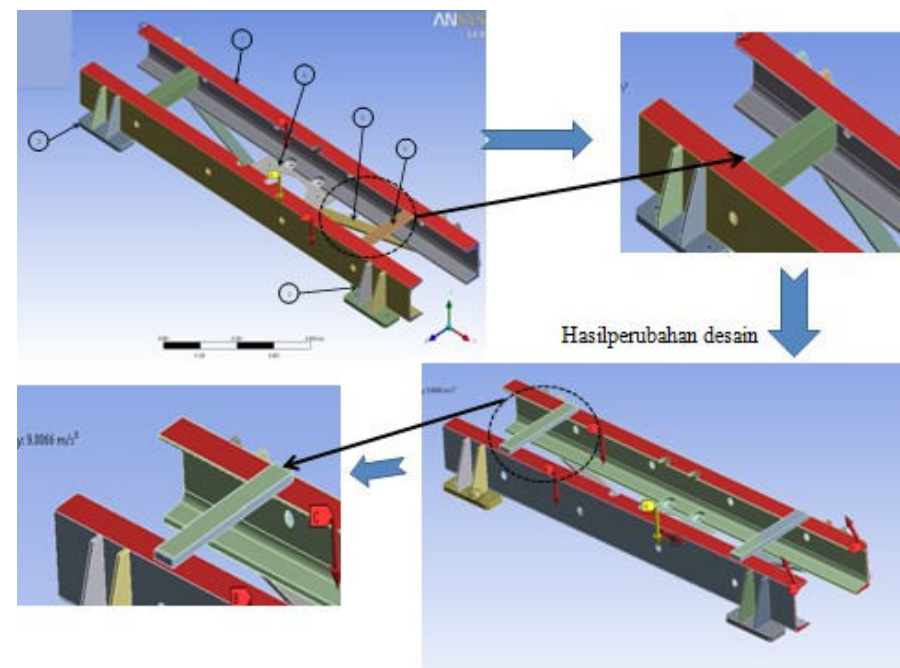

Gambar 5. Struktur dudukan bogie

\section{MESHING PROCESS}

langkah setelah proses pemodelan adalah proses meshing. Hasilnya dapat dilihat pada Gambar 6.

Meshing Sebelum Perubahan Desain Meshing Sesudah Perubahan Desain 


\section{Jurnal Teknik Mesin: CAKRAM 2019}

Muhammad Awwaluddin, Analisis Fatigue Life Struktur Dudukan Bogie Monorail Utm 125 Kapasitas 24 Ton Menggunakan Metode Finite Element
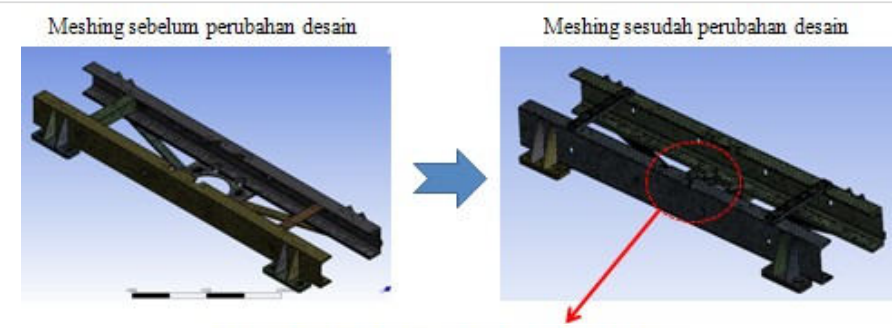

Hasil Perbeșaran:MeskingsesudabuRientbahan Desain

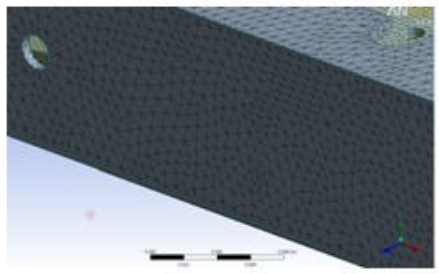

Gambar 6. Hasil meshing pada ansys.

Hasil proses meshing diperoleh elemen sebanyak 265741 dan node sebanyak 483751 serta derajat kebebasan sebanyak 1451253. kualitas element dapat dilihat pada Gambar 7.

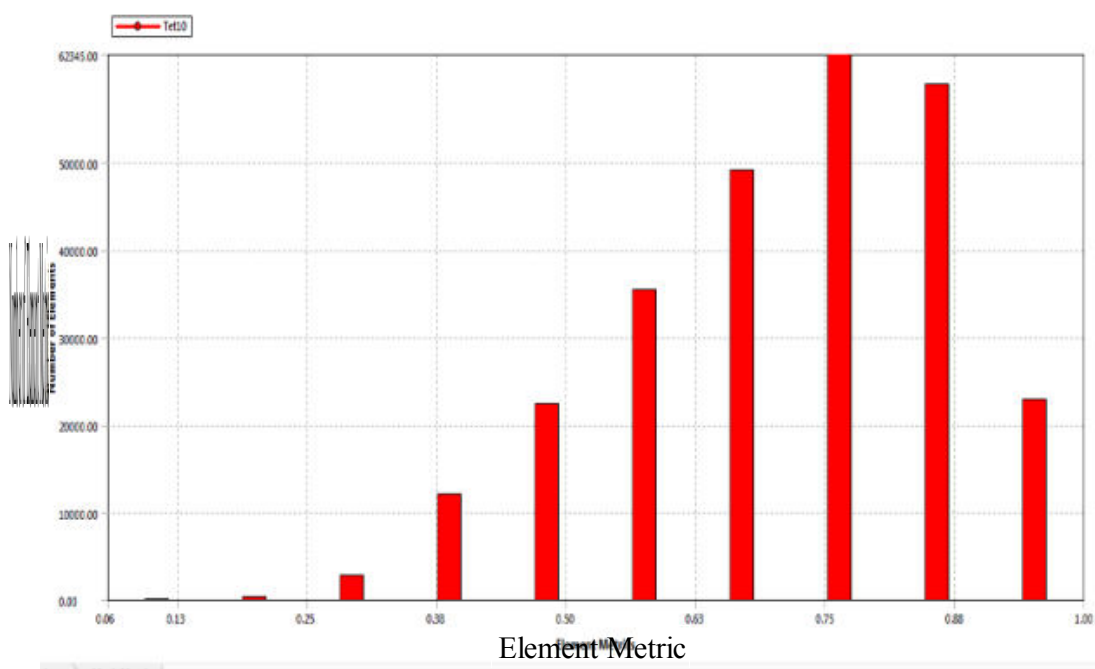

Gambar 7. Hasil Pengecekan kualitas element

Kualitas element yang diperoleh dari hasil proses meshing masuk dalam kategori kualitas elemen yang baik. Dengan kualitas elemen tersebut dapat diteruskan kelangkah selanjutnya pada pembebanan fatigue sampai langkah solusi.

\section{PEMODELAN SUPPORT DAN PEMBEBANAN}

Proses pembebanan pada struktur dudukan bogie dirancang dengan memperhitungkan beban yang diterima sebesar 12 ton. Hal inii didasarkan pada beban maksimal gerbong sebesar 24 ton dan dibagi kedalam dua struktur dudukan bogie. Beban terdiri dari: beban hidup (life load), beban angin, Equipment load, dan longitudinal load. Struktur dudukan bogie di support pada bagian bawah yang akan terhubung dengan bogie. Support arah samping 


\section{Jurnal Teknik Mesin: CAKRAM 2019}

Muhammad Awwaluddin, Analisis Fatigue Life Struktur Dudukan Bogie Monorail Utm 125 Kapasitas 24 Ton Menggunakan Metode Finite Element

diberikan sebagai assumsi adanya tiang pada struktur dudukan bogie sebagai penguat gerbong monorail. Pemodelan dapat dilihat pada gambar 8. Dibawah ini.

\section{Support and Loading}

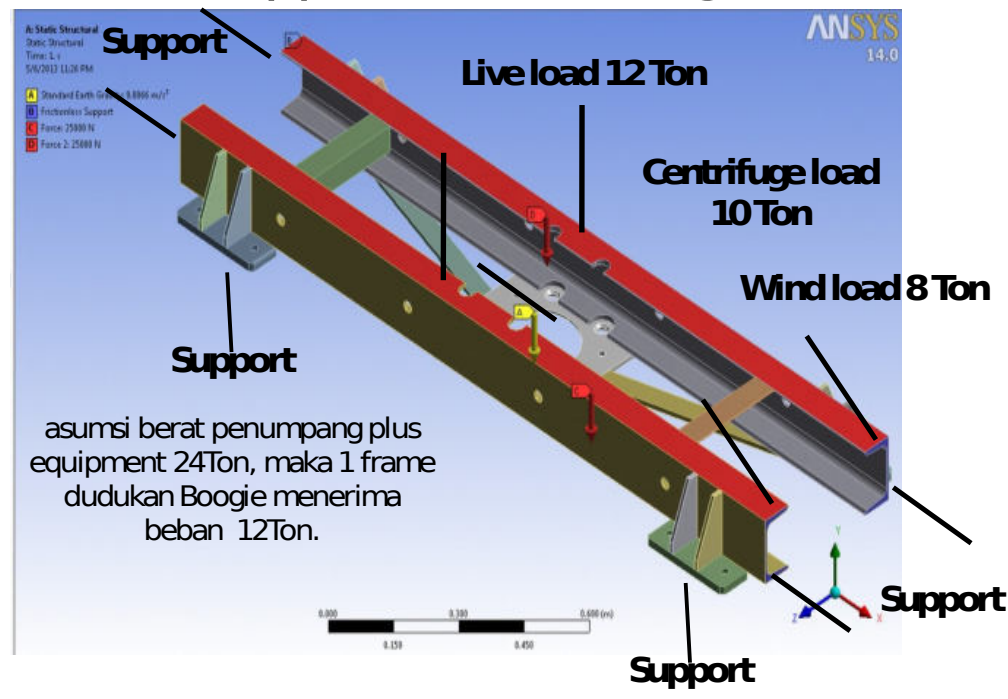

Gambar 8. Pemodelan Support dan Pembebanan.

\section{HASIL ANALISIS DAN PEMBAHASAN}

Dengan asumsi bahwa 1 cycle berlangsung selama 1 detik serta toleransi beban plus minus $20 \%$, maka diperoleh hasil pada Gambar 9.

Fatigue Life

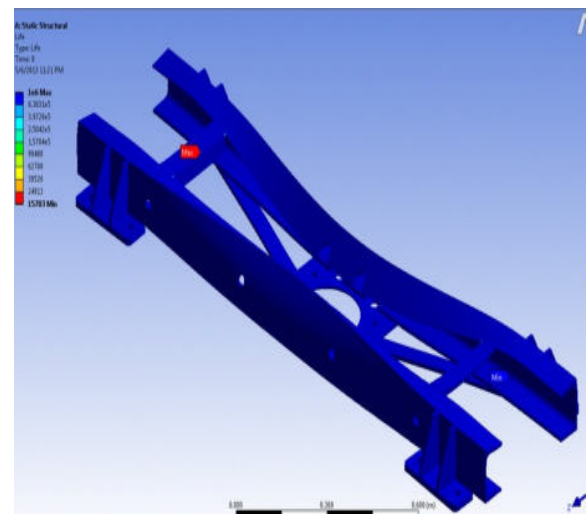

$$
\begin{aligned}
& \text { Life Max: 1e6cyde } \\
& \text { Life Min : } 15703 \text { cyde }
\end{aligned}
$$
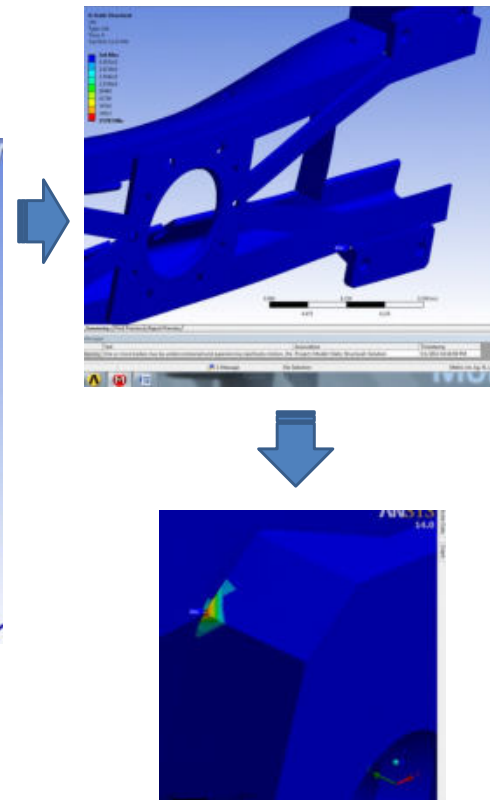

Gambar 9. Hasil solusi 1 fatigue life pada desain lama

Hasil anlaisis ini didapatkan life max sebesar 1e6 cycle, namun masih didapatkan life minimal sebesar 15703 cylce yang artinya masuk kategori low cycle sehingga perlu dilakukan perubahan desain dan proses diulang seperti 


\section{Jurnal Teknik Mesin: CAKRAM 2019}

Muhammad Awwaluddin, Analisis Fatigue Life Struktur Dudukan Bogie Monorail Utm 125 Kapasitas 24 Ton Menggunakan Metode Finite Element

awal. Perubahan dilakukan dengan memberikan chamfer pada daerah yang low cycle dan hasilnya dapat dilihat pada gambar 10. Setelah dilakukan champer ternyata life minimalnya naik menjadi 19674 cycle. Daerah life minimalnya juga berpindah sehingga perlu dilakukan perbaikan lagi pada area tersebut.

(1)

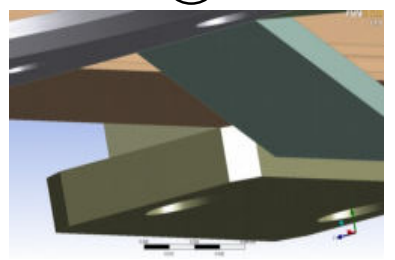

(2)

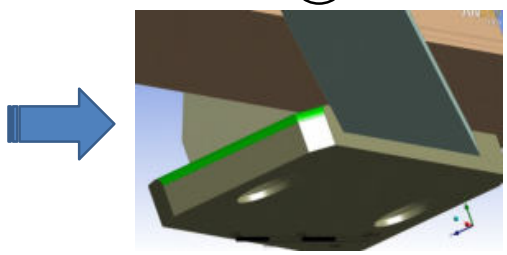

Fatigue Life
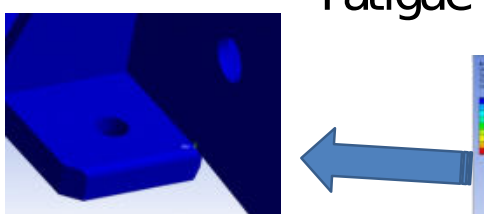

Life Max: 1e6 cycle Life Min : 19674cyde

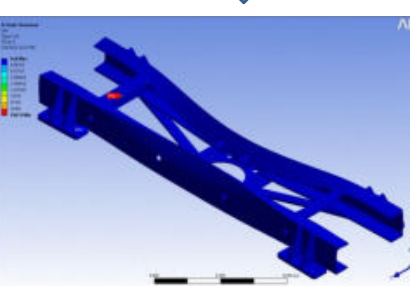

Gambar 10. Hasil solusi 2 fatigue life pada desain lama

Perbaikan desain dilakukan dengan melakukan chamfer pada area dua dan didapatkan hasil fatigue life max 1e6 cycle dan fatigue life min 45475 cycle. Dari hasil memang menunjukkan kenaikan namun masih dalam batas low cycle sehingga harus dilakukan perbaikan. Hasil solusi 3 dapat dilihat pada gambar 11 dibawah ini:

(2)
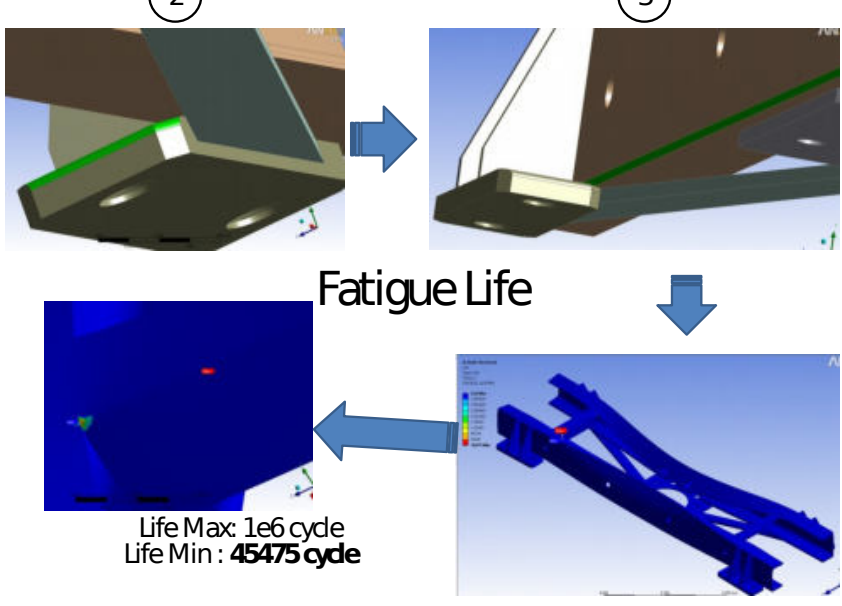

Gambar 11. Hasil solusi 3 fatigue life desain lama 


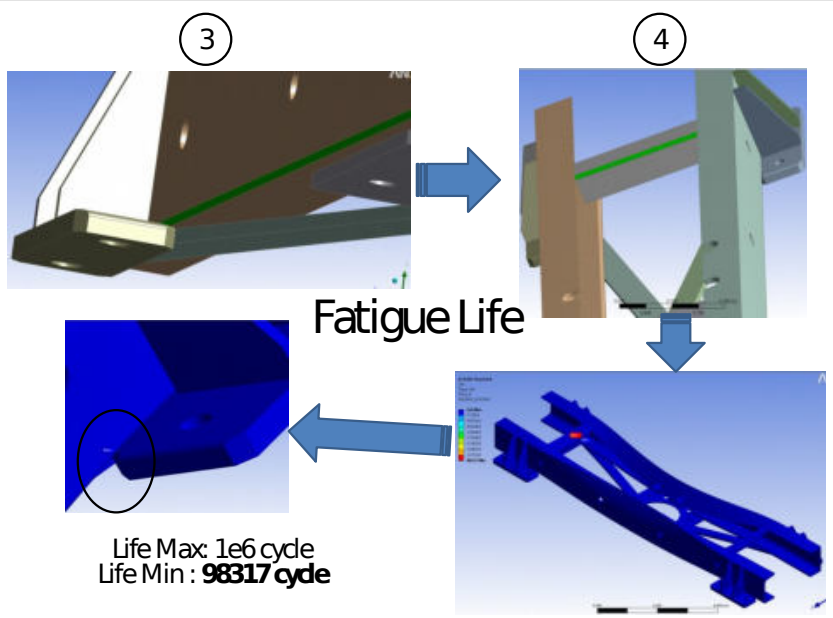

Gambar 12. Hasil solusi 4 fatigue life desain lama

Pada solusi 4 seperti pada gambar 12. telah dilakukan perubahan pada desain solusi 3 namun masih dalam batas low cycle sehingga perlu dilakukan perubahan desain seperti pada solusi 5. Hasil solusi lima adalah:

(4)
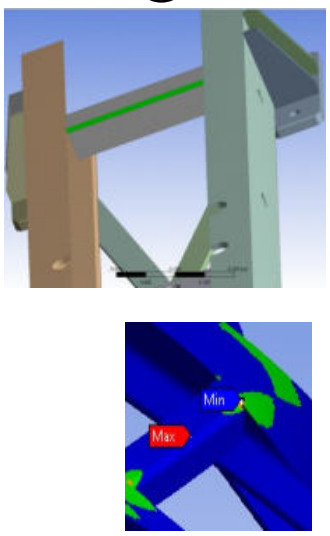

Life Max: 1e6 cyde Life Min : 1,1482e5cyde
(5)

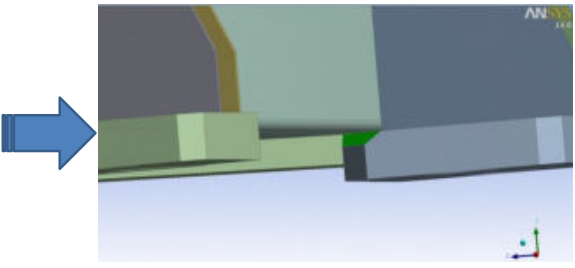

Fatigue Life

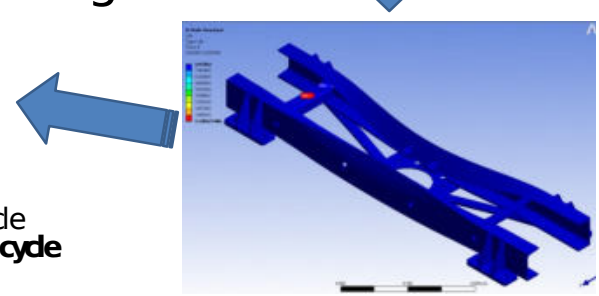

Gambar 13. Hasil solusi 5 fatigue life pada desain lama

Dari hasil solusi 5 dapat dilihat bahwa fatigue life minimal adalah 1,1482e 5 cycle yang berarti sudah masuk kedalam high cycle ( finite life).

Selain dilakukan solusi untuk fatigue life juga dilakukan solusi untuk mengetahui nilai von-misses stress nya pada analisis fatigue untuk setiap tahapan dapat dilihat pada Gambar 14: 


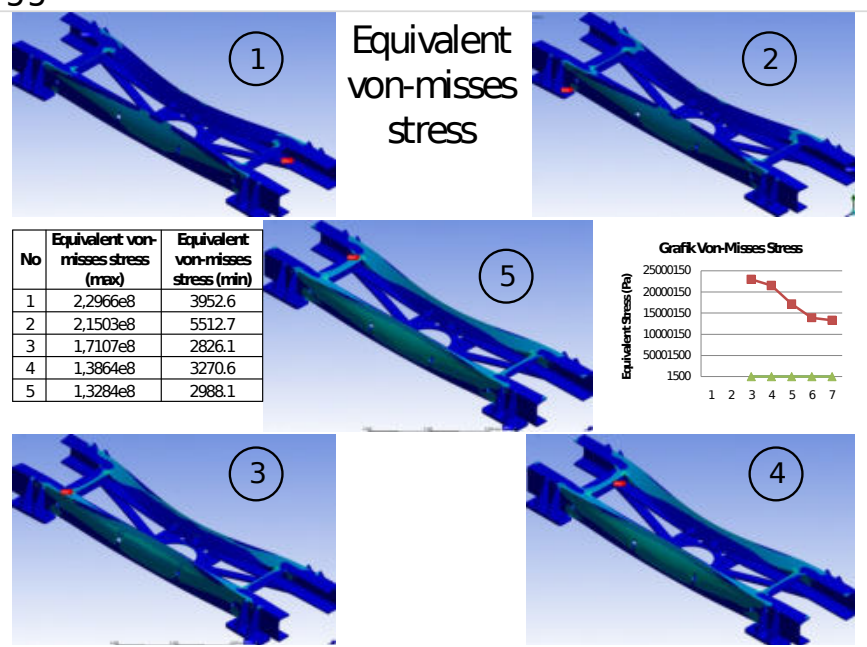

Gambar 14. Hasil solusi equivalent von-misses stress untuk tiap tahapan solusi.

Dari hasil yang diperoleh dapat dilihat bahwa solusi equivalent von-misses stress nomor 5 lebih baik diantara yang lain, hal ini ditunjukkan pada tabel dan grafik yang ada pada gambar 14.

Dilakukan juga solusi untuk deformasi yang terjadi pada masing masing tahapan perbaikan dapat dilihat pada Gambar 15 .

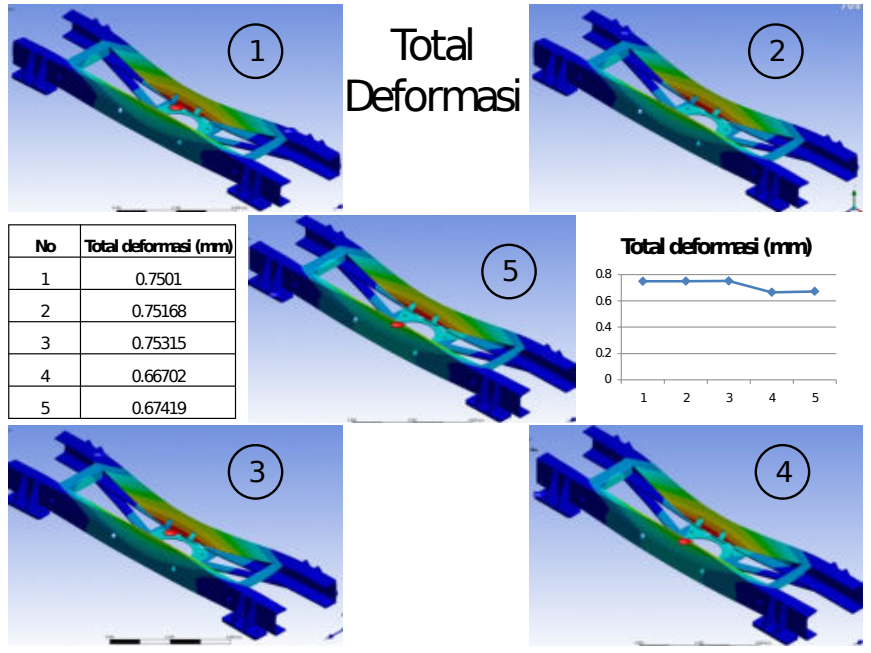

Gambar 15. Hasil solusi total deformasi untuk setiap tahapan perbaikan.

Total deformasi terkecil pada solusi ke 4 kemudian diikuti solusi nomor 5. dapat dilihat pada tabel dan grafik pada Gambar 15.

Dikarenakan hasil maksimal yang didapatkan belum memenuhi kriteria yang dipersyaratkan maka dilakukan perubahan desain seperti terlihat pada gambar 5. Hasil analisisnya adalah sebagai berikut:

Tabulasi data equivalent von-misses stress akibat pembebanan statis selama 1 detik dengan 5 step adalah sebagai berikut: 
Jurnal Teknik Mesin: CAKRAM 2019

Muhammad Awwaluddin, Analisis Fatigue Life Struktur Dudukan Bogie Monorail Utm 125 Kapasitas 24 Ton Menggunakan Metode Finite Element

\begin{tabular}{|c|c|c|c|}
\hline \multicolumn{4}{|c|}{ Tabular Data } \\
\hline & Time [s] & $\sqrt{\sqrt{ }}$ Minimum $[\mathrm{Pa}]$ & $\sqrt{\sqrt{ }}$ Maximum $[\mathrm{Pa}]$ \\
\hline 1 & 0.2 & 354.05 & $2.4342 \mathrm{e}+007$ \\
\hline 2 & 0.4 & 351.03 & $2.1592 e+007$ \\
\hline 3 & 0.6 & 347.18 & $2.159 \mathrm{e}+007$ \\
\hline 4 & 0.8 & 346.76 & $2.1589 e+007$ \\
\hline 5 & 1. & 346.8 & $2.1589 e+007$ \\
\hline
\end{tabular}

Gambar 16. Tabulasi data Equivalent von-mises stress desain perubahan dengan pembebanan statis

Fatigue life yang diperoleh dari hasil analisis dengan asumsi 1 cycle berlangsung selama 1 detik dan toleransi pembebanan plus minus $20 \%$ dapat dilihat pada gambar dibawah ini.

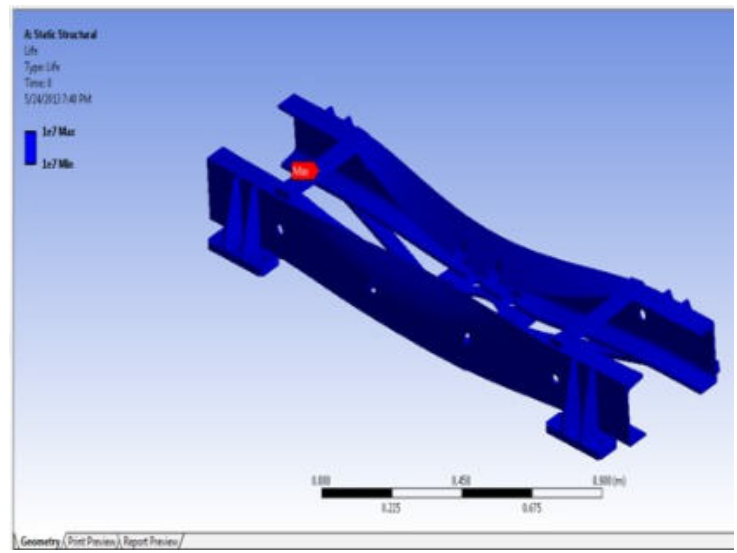

Gambar 17. Hasil solusi fatigue life desain baru

Dari hasil analisis dapat dilihat bahwa fatigue life struktur mencapai 1e7 setelah dilakukan perubahan desain dengan mengganti suppot siku 60 menjadi pelat dengan tebal $15 \mathrm{~mm}$, lebar $60 \mathrm{~mm}$, panjang $250 \mathrm{~mm}$.

Safety faktor dari struktur yang sudah diperbaiki dapat dilihat pada gambar dibawah ini.

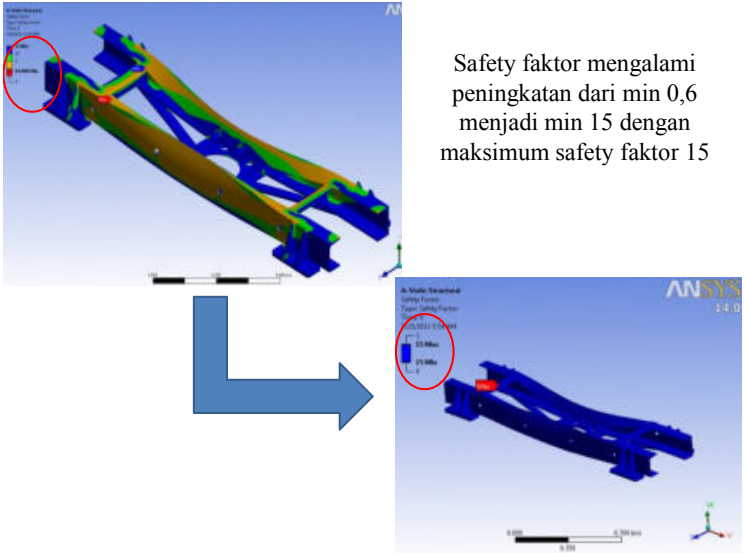

Gambar 18. Hasil solusi sefaty faktor analisis fatigue desain lama dan desain baru

Dari hasil analisis dapat dilihat bahwa safety faktornya mencapai 15. 


\section{KESIMPULAN}

Kesimpulan yang dapat diperoleh dari penelitian ini adalah:

1. Desain struktur dudukan bogie yang diperbaharui telah memenuhi batas nilai fatigue life yang ditentukan dengan nilai maksimal fatigue life 1e7 cycle dan fatigue life minimal 1e7 cycle.

2. Safety faktor struktur setelah perubahan desain mengalami peningkatan dari 0,649 menjadi 15 .

3. Hasil perhitungan manual $\sigma_{a}$ efektif tidak jauh berbeda dibandingkan hasil perhitungan $\sigma_{a}$ efektif pada software. Hal ini terlihat pada Gambar 8.

4. Faktor bentuk sangat mempengaruhi nilai fatigue life, hal ini dapat dilihat pada hasil dari tiap tahapan dan hasil perbaikan desain.

5. Untuk meningkatkan nilai fatigue life dapat dilakukan dengan membentuk chamfer, fillet atau menghaluskan permukaan, mengganti bentuk part ataupun mengganti material.

\section{DAFTAR PUSTAKA}

[1] Jung-Kyu Kim, Dong-Suk Shim, " The variation in fatigue crack growth due to the thickness effect", International Journal of Fatigue, Vol. 22, 2000, pp. 611-618.

[2] R. Kieselbach, "Curious cases of failure", Engineering Failure Analysis, Vol. 11, 2004, pp. 501-513.

[3] Volker Esslinger, Rolf Kieselbach, Roland Koller, Bernhard Weisse," The railway accident of Eschede technical background", Engineering Failure Analysis, Vol. 11, 2004, pp. 515-535.

[4] A.J. McEvily, " Failures in inspection procedures: case studies", Engineering Failure Analysis, Vol. 11, 2004, pp. 167-176

[5] Muhammad Awwaluddin, dkk “ Analisa Fatigue Life Struktur Mekanik Pasien Pada Perangkat Renograf Terpadu Menggunakan Metode Finite Element”, Jurnal Perangkat Nuklir, Volume 09, Nomor 01, Juni 2015, pp. $37-48$.

[6] A. Jalil, Awwaluddin M., “ Analisis Kelelahan Pada Struktur Landasan Rangka Pada Perekayasaan Pesawat Sinar-x Digital Menggunakan Metode Elemen Hingga, Jurnal Perangkat Nuklir, Vol. 07, No. 01, Juni 2013, pp. 41-50.

[7] Haftirman, The Size Effect on Fatigue Strength of Structural Steel Materials in High-humidity Environment, Proceedings of International Conferences on Applications and Design in Mechanical Engineering, Malaysia, 2009.

[8] L. Raymond., E. P. Browell. “ Predicting Fatigue Life with ANSYS Workbench”, International ANSYS Conference May 2-4, 2006.

[9] Popov, E.P., Mechanics of Materials, Berkeley, California, 1984.

[10] Oberg, Erik., Jones, Franklin., Horton, Holbrook., Ryffel, Henry., McCauley, Christopher., Machinery's Handbook 29th Edition, 2012 
Jurnal Teknik Mesin: CAKRAM 2019

Muhammad Awwaluddin, Analisis Fatigue Life Struktur Dudukan Bogie Monorail Utm 125

Kapasitas 24 Ton Menggunakan Metode Finite Element 